\title{
ІНСТРУМЕНТИ ЕФЕКТИВНОЇ КОМУНІКАЦІЇ ДЛЯ ВИКЛАДАЧІВ ІНОЗЕМНИХ МОВ ПЕДАГОГІЧНОГО ЗВО
}

\author{
(C) Бельмаз Я.М., 2019 \\ https://orcid.org/0000-0002-8823-640X \\ (C) Сергссва I.C., 2019 \\ https://orcid.org/0000-0003-0973-3078 \\ http://doi.org/10.34142/2312-2471.2019.62.01
}

Ефективність традиційного авторитарного стилю в спілкуванні зі студентами різко знижується з приходом покоління $Z$ до університетів, щуо призводить до иілої низки негативних наслідків, від зниження якості навчання до зміни напрямку та навчального закладу студентами. Разом із тим, викладацька спільнота не завжди володіє навичками конструктивного спілкування, щзо постають ефективною альтернативою застарілим інструментам, таким як загрози, иантаж, приниження. Мета статті проаналізувати та продемонструвати викладачам іноземних мов педагогічних вищих навчальних закладів ефективні засоби конструктивної комунікації, щзо дозволять покращити якість їх професійної діяльності та підвисити конкурентоспроможність вітчизняної системи педагогічної освіти. У статті розглянуто 5 інструментів конструктивної комунікації та наведено конкретні приклади їх застосування на заняттях з іноземної мови у вищому навчальному закладі педагогічного спрямування. Ненасильницьке спілкування (формулювання висловлення від першої особи, експліциттне вираження емоцій, потреб та вимог), Я-повідомлення (формулювання висловлення від першої особи) являють собою конструктивну альтернативу оціночним судженням та $\epsilon$ інструментами, щзо дозволяють надавати ефективний та неконфліктний зворотній зв'язок студентам, віддавати вказівки у максимально прийнятній для адресатів формі. Постановка цілей за SMART запропонована як модель, щуо легко інтегрується до ненасильницького спілкування, $i$ дозволяє якісно формулювати навчальні цілі. Позитивне обрамлення та точна похвала містять конкретні рекомендації щуодо типових проблемних зон у наданні зворотного зв'язку та націлені на встановлення та утримання сильної позиції викладача, стимулювання бажаних типів поведінки студентів, мінімізації конфліктів у ході навчальної діяльності. 3 метою максимального підвищення практичної иінності дослідження, усі комунікативні інструменти розглянуто на прикладах 6 типових робочих ситуачій, щзо виникають у процесі вивчення іноземних мов.

Ключові слова: ненасильницьке спілкування, Я-повідомлення, викладання іноземних мов, конструктивна комунікація. 
Belmaz Ya., Sergieieva I. Constructive Communication Tools for Foreign Languages Teachers of Pedagogical Universities

The effectiveness of authoritarian communication strategies (threats, blackmail, screaming, humiliation), still used in education, is decreasing with the advent of generation $Z$, which highly values constructive communication styles, and tends to consider them as a priority factor when choosing a place of work or study. The purpose of the article is to demonstrate the tools of constructive communication to teachers of pedagogical universities that they can actively use in teaching and pass on to students for their further professional activities. The article deals with the issue of the means for constructive communication and their application in teaching foreign languages. Non-violent communication, and I-Message, which is in the fact that the statement is formulated in the first person, are considered as tools to give clear feedback in the most acceptable for students form. As well as those that help teachers and students to save resilience due to empathy, auto-empathy, awareness of their own needs, reduction of stress level. Setting goals for SMART is proposed as a tool for effectively setting clear, measurable, achievable, relevant, and time-limited learning objectives. Positive framing and accurate praise, containing clear recommendations for providing feedback and correcting student behavior, are tools that allow a teacher to remain a strong position, but to interact effectively with students, helping them learn the necessary life and learning skills. The combination of tools allows to establish high-quality relationships with students, reduce stress on all participants in the educational process, create a positive climate and work atmosphere in the classroom.

Keywords: non-violent communication, I-Message, teaching foreign languages, constructive communication

Постановка проблеми. Факультети іноземних мов педагогічних закладів вищої освіти стикаються 3 низкою нових для України проблем. Уперше зменшення кількості студентів пов'язане не лише зі зниженням народжуваності наприкінці 1990-х - початку 2000-х років, а й зі зростаючою мобільністю абітурієнтів та студентів. Українські виші масово конкурують не лише між собою, а й з європейськими коледжами та університетами.

3 одного боку, викладачі є свідками того, як старі методи та інструменти спілкування, успадковані 3 попередніх епох, виявляються не лише неефективними, а й призводять до конфліктів, зниження академічної успішності студентів, стають причиною відмови від продовження навчання. Протягом останніх років викладачі змушені адаптуватися до падіння залученості молоді у навчальний процес, відсутності внутрішньої мотивації, орієнтації на зовнішні чинники, розважальну й ігрову складові навчання, прагнення студентів використовувати гаджети і інтернет, що негативно впливає на надбання власних знань і навичок, включаючи базові.

Описані тенденції викликані низкою факторів, і не в останню чергу пов'язані з особливостями покоління Z, що масово прийшло до студентських 
лав, з яким старшим викладачам складно знайти спільну мову. Покоління Z та способи ефективної взаємодії з ним все частіше стає предметом професійного обговорення.

3 іншого боку, за останні 20 років з'явилася низка досліджень, що пояснюють особливості роботи людського мозку та доходять до контрінтуїтивних висновків, спростовуючи домінуючу роль раціонального компоненту у прийнятті рішень, констатуючи визначальну роль емоцій у навчанні та професійній діяльності. На жаль, їх результати не завжди відомі професійній викладацькій спільноті; окрім того, часто викладачі не вбачають шляхів конкретної реалізації цих наукових даних.

Інструменти конструктивного спілкування знаходяться на перетині означених проблемних полів та розглядаються у статті як конкретний i практичний варіант їх часткового вирішення - i встановлення робочих стосунків з сучасним студентством.

Аналіз останніх досліджень і публікацій. У визначенні важливих для покоління Z пунктів дана робота спирається на два масивних дослідження. Перше відбулося у 2015 році, коли компанія BNP Paribas Group у партнерстві 3 The Boson Project у 2015 році опитали 3200 французів від 15 до 20 років [4]. Друге дослідження пройшло у 2018 році: група Dell Technologies анкетувала 12000 студентів по всьому світу [7]. Результати обох досліджень отримали широкий відгук у західній пресі, адже в них було з'ясовано, що, окрім розваг, у професійному житті покоління Z націлене на:

- етику, що є вирішальним фактором для 21\% молодих людей при виборі (майбутньої) роботи;

- міжнародне спілкування в мажах професійного та особистого життя, значуще для 37\% опитаних, які бажають подорожувати по роботі, і 69\%, що прагнуть працювати за кордоном;

- pізноманітність: як у легкості зміни сфери діяльності, так і географічної та горизонтальної мобільності на роботі;

- гуманний менеджмент: здатність керівництва слухати i довіряти підлеглим важливі для 62\% і 67\% опитаних відповідно;

- технологіï: 80\% Z хочуть працювати з високими технологіями.

Важливість «гуманного менеджменту» (а викладача все частіше розглядають саме як менеджера по відношенню до студентської спільноти) в освітньому середовищі підтверджують дані нейронауки $[3 ; 6 ; 8]$, отримані в ході численних досліджень та популяризовані у низці видань, про нищівну дію стресу на мозок, що формується до 25 років, зв'язок ефективності навчання 3 емоційним комфортом, важливість якісного зворотного зв'язку, панівну роль емоцій у прийнятті рішень $[9 ; 11 ; 13]$.

Виділення невирішених раніше частин загальної проблеми. На наше переконання, ще недостатньо наукових робіт, що пропонували б адаптацію ефективних комунікативних інструментів під потреби викладання іноземних мов у педагогічних ЗВО. 
Усі запропоновані нами нижче у статті комунікативні інструменти покликані та дозволяють знизити стрес студентів та викладачів протягом навчальної діяльності, встановити позитивні стосунки, націлені на виконання спільних завдань, надати якісний зворотний зв'язок та знизити рівень конфліктності в аудиторіях та поза стінами вищих навчальних закладів, а отже, сприяють вирішенню вищеозначених проблем.

Мета статті - розглянути 5 інструментів конструктивної комунікації, які показали свою ефективність в освітньому середовищі: ненасильницький спілкування, Я-повідомлення, цілепокладання по SMART, точну похвалу i позитивне обрамлення; продемонструвати конкретні можливості їх застосування у вивченні іноземних мов.

Для ілюстрації використання інструментів у навчальному середовищі факультету іноземної філології педагогічного вишу, ми вибрали для прикладів типові навчальні ситуації: А: погано виконаний тест; В: розмови на заняттях; $\mathrm{C}$ : несанкціоноване використання гаджетів; D: нерозбірливий почерк студента; $\mathrm{E}$ : успішно зроблене завдання; F: необхідність дати студентам самостійне завдання. Вони знайомі більшості викладачів іноземних мов, тому допоможуть яскравіше розкрити переваги запропонованих комунікативних інструментів.

Виклад основного матеріалу. Ненасильницьке спілкування (далі застосовуватиметься абревіатура НHC) Маршалла Розенберга [5] i $Я$ повідомлення Томаса Гордона [2] популяризовано на пострадянському просторі спочатку відомою дослідницею і практиком Ю. Б. Гіппенрейтер, а згодом в Україні й проектом Empatia.pro і багатьма іншими. Найчастіше їх розглядають як незалежні один від одного, але вони мають схожу спрямованість; крім цього, Я-повідомлення легко вбудовується в схему ненасильницького спілкування.

Обидва інструменти базуються на співпереживанні, (само)повазі, безконфліктному досягненні мети. ННС включає три типи процесів, до яких відносяться самоемпатія (прислухатися собі з метою усвідомлення і прийняття власних емоцій); створення максимально прийнятної форми власних повідомлень; сприйняття повідомлень співрозмовника (студента), спрямоване на встановлення діалогу і гармонізацію відносин в будь-якій ситуації.

Необхідні умови для застосування ННС - увага до поточного моменту і прагнення встановити та підтримати діалог і співпрацю з боку викладача.

ННС включає чотири етапи:

1. Спостереження: викладач описує ситуацію, яка розгортається перед ним;

2. Почуття і ставлення: викладач висловлює свої почуття, викликані ситуацією, і ставлення до неї (саме сюди можливо успішно вбудувати технологію Я-повідомлень);

3. Потреба, або потреби ситуації: він називає і уточнює потребу чи необхідність, що виникла у нього у зв'язку з ситуацією;

4. Прохання (вимога): він формулює своє прохання або вимогу, що відносяться до дій студентів. Той факт, що прохання супроводжується 
висловленням потреби, що призвела до нього, робить можливим його обговорення зі студентами.

Залежно від потреб ситуації, порядок етапів може бути довільним, але артикуляція всіх чотирьох етапів є необхідною умовою.

Головна вимога до етапу спостереження в ННС - об'єктивність викладача при описі ситуації, відмова від оціночних суджень й упередженості в іï інтерпретації. На думку М.Розенберга, «безоціночне спостереження - це найвищий прояв людського розуму» [5, с. 24]. Воно дозволяє попереджати конфлікти, оскільки, відчуваючи, що його не оцінюють і не приписують його вчинкам несправжню мотивацію, студент проявить більший інтерес і розуміння до слів викладача. Приклад безоціночного опису:

A: Маріє, Ви правильно виконали 60\% завдань тесту з використання артиклів;

В: В аудиторії иумно;

C: Я бачу 4 телефони, які лежать на столах;

D: Я не в змозі розібрати Ваш почерк;

E: 2 студента виконали завдання на максимальний бал.

Завдання другого етапу - створення Я-повідомлення, яке завжди формулюється від першої особи і присвячено почуттям суб'єкта висловлювання. Не допускається включення до висловлення оціночних характеристик щодо студента. Наприклад (в дужках наведені типові Тивисловлювання викладача, що містять оцінку або прямі звинувачення, i тому малоефективні):

A: Мені сумно (я розчарований, здивований), щзо Ви виконали 60\% завдань при прохідному балі 70\% (vs Ви погано виконали завдання);

B: Мені важко пояснювати, коли в аудиторї шумно (vs Ви занадто галасуєте! Скільки можна шуміти!);

С: Я здивований, побачивии, шзо 4 телефони лежать на столах, коли я сказав їх відкласти (vs Ви щуо, не чули? Швидко відкладіть телефони!);

D: Я здивований, тому щзо не в силах розібрати Ваш почерк (vs Ви жахливо пищете);

Е: Я радий (гордий), щуо 2 студента виконали завдання на максимальний бал. (vs Ви такі розумні).

Необхідною умовою коректної реалізації даного етапу ННС є розвинений емоційний інтелект викладача.

Важливість третього етапу обумовлена потребою студента в проміжній причині між почуттями викладача і діями, яких він очікує від студентів.

A: Ви не набрали мінімальний прохідний бал в тесті з артиклів, який дає 20\% модульної оцчінки $і$ необхідний, щзоб бути допущзеним до проходження модульного контролю. (vs Перепишіть тест);

В: Для того, щзоб пояснити вам цүю складну тему, мені необхідна тима в аудиторії (vs Замовкніть!);

C: В нашій групі існують правила щуодо використання мобільних телефонів, і їх необхідно дотримуватися (vs Сховайте телефони, я сказав!); 
D: Я не можу оиінити Ваше завдання гідно, коли воно написано нерозбірливо (vs Перепишіть його);

E: Мені важливо знати, щуо наш з вами праия приносить позитивні результати (vs Старайтеся ще).

До причин, що перешкоджає вираженню потреб викладачем, відносяться: відсутність досвіду висловлювати свої потреби; нестача лексичних засобів; переконаність у тому, що вираження почуттів і потреб є ознакою слабкості (в т.ч., в силу культурних особливостей); впевненість, що студент не зможе адекватно реагувати на висловлення почуттів і потреб викладача; соціальні установки, які засуджують висловлення емоцій; недостатньо розвинений емоційний інтелект. Всі вони можуть бути усунуті в ході навчання викладачів даної технології (тренінги, інтенсивні програми, самоосвіта).

Головна перевага ННС в освітньому середовищі полягає в тому, що воно дозволяє відмовитися від погроз, шантажу, маніпуляцій, використовуючи тільки прохання і вимоги, що відрізняються зрозумілістю, експліцитно, чіткістю, простотою, використанням активних і ствердних конструкцій, i, таким чином, знизити стрес студентів [3, с. 24].

Постановка иілей за SMART, запропонована Полом Мейером для бізнесу, зокрема, для менеджменту і проектного управління, і розвинена Джорджем Дораном в 1981 [1], добре узгоджується з четвертим пунктом ННС (прохання / вимога), і з постановкою навчальних завдань у цілому .

SMART - мнемонічна абревіатура, яка розшифровує основні вимоги до формулювання цілей: Specific (конкретна, специфічна), Measurable (така, що піддається вимірюванню), Attainable (така, що може бути досягнена), Relevant (релевантна), Time-bounded (визначена у часі). Розглянемо принципи SMARTпідходу і приклади його застосування в процесі викладання іноземних мов також на ситуації із завданням для самостійного вивчення студентами протягом третього етапу навчання. Отже, будь-яке завдання або мета мають відповідати таким критеріям:

Specific: викладач повинен максимально точно i конкретно сформулювати завдання для студентів.

A: Повторіть тему артиклів, зверніть увагу на вживання артикля 3 власними іменами, і перескладіть завдання;

В: Припиніть розмови;

C: Приберіть телефони в сумки $і$ закрийте їх;

D: Перепишіть завдання розбірливо, або роздрукуйте;

Е Продовжуйте прачювати з такою ж наполегливістю.

F: Вам потрібно запам'ятати відмінювання відхиляються дієслів у минулому закінченому часу. Для иъього слід виконати всі завдання иъого модуля, призначені для самостійної роботи. Такі завдання в робочих зошитах позначені таким символом*;

Measurable. Що точніше сформульовано обсяг роботи, то краще його зрозуміють студенти. 
A: Вам буде достатньо матеріалів, наведених у підручнику, робочого зошита та статті (п.3 додаткового списку літератури);

В: Припиніть всі розмови;

C: На столах не повинно бути жодного гаджета;

D: Роздрукуйте своє завдання на принтері шрифтом Arial, 14 кеглем;

E: Продовжуйте заданий ритм до кіния семестру.

F: У модулі 6 завдань із зірочкою.

Attainable. Реалістично поставлені цілі. Зробити 6 завдань протягом часу, поки вивчається модуль - досяжно і реалістично, а, наприклад, на протязі трьох днів до настання точки модульного контролю, або на перерві - ні. Завдання викладача в такому випадку - ставити перед студентами мету, яку вони в принципі здатні виконати.

A: Ви зможете підготуватися до перездачі тесту за півтора тижні?

В: Якщо телефони не вміщаються в сумки, складіть ӥх на мій робочий стіл;

C: Помовчіть, поки я пояснюю. Якщо у Вас виникають питання, запишіть їх $i$ задайте, коли я закінчу пояснення. Для сторонніх розмов $\epsilon$ перерва;

E: Протягом сесії та на канікулах Ви зможете зменшити темп $i$ відпочити.

F: Якщо Ви приступите до виконання завдань на цьому тижні, $i$ будете робити по два завдання в тиждень, Ви встигнете виконати їх спокійно $i$ якісно.

Relevant - доречність по відношенню до контексту. Чи дійсно поставлені завдання сприяють досягненню мети? Для того, щоб вивчити дієслівні форми i навчитися їх застосовувати, потрібно виконати вправи на відмінювання, подивитися фільм або сходити на культурний фестиваль? Завдання викладача підбирати завдання, максимально ефективні для досягнення навчальних цілей, $\mathrm{i}$ якщо треба, пояснювати студентам цей взаємозв'язок.

A: Здавши тест на 70\% і більще, Ви будете допущені до модульного оичнювання;

B: Гаджети заважають Вам зосередитися, а використання автоперекладачів не дозволяє надбати навичок самостійного перекладу та розуміння тексту;

C: В тиші мені простіше працювати, а вам - сприймати складні теми;

D: Будь-яка людина добре сприйме Вамі думки, коли вони будуть викладені в доступній формі.

E: При такому рівні зосередженості на навчанні Ви не тільки надбаєте міцних знань, а й отримаєте максимальні бали в оцінюванні.

F: Всі 6 завдань містять неправильні дісслова в минулому часі, їх виконання допоможе вам запам'ятати їх форми і застосування.

Time-bound. Чіткі часові рамки допомагають студентам підтримувати необхідний темп навчання.

A: Кінцевий термін перездачі тесту через три тижні, час пімов. 
В: Приберіть гаджети негайно.

C: Пояснення займуть 5 хвилин, до перерви залишилося півгодини. Якщо у вас важливі і термінові питання, я можу дати вам 3 хвилини на обговорення.

D: Я чекаю Ваше завдання до 17.00 четверга.

E: Ви пам'ятаєте, що до кінияя занять залишився місяиьь, сесія триватиме ще 20 днів.

F: Цей модуль займає три тижні, останній термін складання всіх завдань - третя п'ятниия листопада. Ви також можете здавати їх частинами, починаючи з найближчого вівторка.

Позитивне обрамлення, пропоноване дослідником Дугом Лемовим [10, с. 269], засноване на послідовній позитивної корекції поведінки студентів із застосуванням цілеспрямованої похвали і конструктивної критики. Діяльність викладача спрямована утримання сильної позиції при формуванні і підтримці в студентів бажаних типів поведінки чи діяльності, а також на те, щоб їх шлях них був прямим i коротким. Для успішного впровадження позитивного обрамлення необхідно дотримуватися низки правил.

Фокус на сьогоденні. На занятті викладач звертає увагу тільки на ту діяльність чи поведінку, яка може бути покращеною. Якщо він усвідомлює, що в поточний момент студенти не в змозі поліпшити той чи інший аспект, він не говорить про нього. Інструкції мають містити конкретні кроки в напряму правильної поведінки.

Відмова від побудови найгірших припущень щодо мотивів вчинків студентів. Демонстрація віри в їх кращі наміри і довіри до них. Викладач виходить із того, що помилкову поведінку студентів продиктовано нездатністю вести себе добре чи діяти коректно через різні обставини (втома, голод, втрата концентрації і т.д.):

A: Я розумію, артиклі - не найцікавіша тема, але ї̈ треба пройти; В: Можллио, ви втомилися, але зосередьтеся, будь ласка; С: Звісно, ви звикли до гаджетів, $і$ з ними зручніше, але ...; D: Можливо, Вам складно писати чітко, але ...; Е: Ви дійсно доклали зусиль.

Відмова від побудови найгірших припущень не виключає застосування дисциплінарних заходів, але робить їх більш прийнятними в очах студентів, а отже, більш ефективними. Дуг Лемов зазначає, що найчастіше при такому підході доведення студента до виконання правильної дії логічно замінює покарання [10, с. 271]. Наприклад: A, F. Роботи і тести, здані із запізненням, не зараховуються (vs Якщо ви не здасте всі вчасно, я їх не зарахую! інформація про санкції vs пряма загроза і демонстрація сили одночасно 3 невірою в неї, оскільки при другому типі висловлювання можливість порушень допускається як така). Ефект посилюється, коли викладач дякує студентам за правильне і своєчасне виконання вказівок.

Виправдана анонімність зауважень у разі поодиноких ненавмисних проступків передбачає можливість не називати імен студентів у зауваженні, дозволяючи їм виправити свою поведінку без зайвого стресу, викликаного згадкою їх імен. Наприклад: А. Четверо осіб з групи не впоралися з тестом (vs 
Іванов і Петрова знову не підготувалися!) С: Дехто забув сховати телефон. Відкладіть його і поверніться до вправи (vs Маріє, скільки можна сидіти в смартфоні!).

Акцентування і максимальне утримання уваги на позитивній динаміці: викладач фокусується на позитивних зрушеннях в діяльності студентів, не позбавляючи їх відповідальності за їхні вчинки. А: Я радий, щзо цього разу група написала тест краще, ніж минулого; В: Стало тихіме, спасибі. Ще двоє осіб припинять базікати - і продовжимо роботу; С: Але мені приємно, щьо більшість з вас дотримуються иього правила без нагадувань; Е: Дивіться, периий абзаи Ви написали досить чітко, зробіть інші три так само.

Д.Лемов зазначає, що фрази типу «Я, як $i$ раніше, чекаю деяких студентів» ставлять викладача у вкрай невигідне становище, і прирівнює їх до висловлювань, на кшталт, «Я дуже слабкий і прошу вас не ображати мене» $[10$, c. 274].

Створення здорової конкуренції, постановка амбіційних завдань, встановлення і підтримання позитивної змагальності. Мета - мотивувати студентів до більш високих досягнень. При цьому студенти можуть змагатися один 3 одним (як індивідуально, так і групами), з часом ( $A, E: H a$ mecm відведено 20 хвилин, але хто зможе зробити його за менший час?), 3 попередніми результатами (Е: Кирило, минулого разу ти набрав у диктанті 95 балів, замахнешся на 100?), з абстрактними суперниками $(F, E:$ у Франиії изі завдання входять в бакалаврський іспит, хочете спробувати?) і т.д.

Обговорення очікувань і прагнень студентів, включення їх у систему мотивації. Знаючи, що студент мріє стати директором школи, викладач може відзначити його відповідальне ставлення до навчання як гідне справжнього директора, або помітити, що воно дозволить йому добитися успіхів у майбутній кар'єрі. Викладачу пропонується відзначати досягнення студентів там, де вони цього заслуговують, максимально акцентуючи бажані якості: E: Mapie, Bu проявили незвичайну наполегливість і прекрасно впорались із завданням! Або $B$, : : Я дуже радий, що сьогодні ваша група змогла по-справжньому сконцентруватися і працювала з великим ентузіазмом.

Точна похвала заснована на даних про те, що особистості, яких хвалять за постійні властивості (розум, талант), в кінцевому підсумку вчаться гірше, ніж ті, яких заохочують за старанність, докладені зусилля, працьовитість. На це звертають увагу низка авторів [3; 12]; ситуації описані в тому вигляді, як їх бачить Дуг Лемов. Будучи набагато більш ефективним, ніж критика і корекція, в разі неправильного використання, позитивне підкріплення втрачає свої переваги. Для того, щоб позитивне підкріплення було дієвим, технологія його використання повинна включати наступні моменти.

Чітка диференціація визнання і похвали. Визнання використовується, коли студент просто виправдовує очікування, а похвала покликана відзначати виняткові досягнення, тому є більш вагомою і використовується в особливих випадках. Визнання повинно використовуватися якомога частіше i може приймати форму подяки або позитивно забарвленого опису вчинку студентів: 
D: Дякую за чітко написане твір, Антон, або $B$ : Сьогодні я пояснював нову тему в повній тиші. Спасибі. На відміну від ненасильницького спілкування, похвала за Д.Лемовим може включати також оціночне судження щодо старань або виконаної роботи студентами: $Е$ : Я бачу, Аліна дійсно добре підготувала свою доповідь. Браво!

Хоча точна похвала рекомендує вдаватися до позитивного підкріплення в три рази частіше, ніж до корекції, вона передбачає відмову від невмотивованої похвали (Які ви молодиі, щуо вивчили закінчення теперішнього часу!), адже надмірні заохочення призводять до зворотного ефекту. «У довгостроковій перспективі викладач, який постійно хвалить за очікуване, ризикує звести до рівня банальності як самі похвали, так i досягнення, які цієї похвали заслуговують» $[10$, с. 278$]$.

Гучне і прилюдне заохочення на тлі тактовного виправлення проступків. I позитивне підкріплення, і критика повинні чітко експлікувати, що саме викладач хоче бачити в поведінці студента: Олено, Ваш переклад дуже точний $i$ витончений. Владу потрібно ще доопрацювати граматику. Заохочення та критика мають охоплювати виключно те, що входить в сферу контролю студента.

Щирість заохочень. Нещира похвала покликана підвищити самооцінку студентів (Я вірю в вас! Все буде добре! Ви молодизі, і т.п.), до того ж неконкретна, має зворотний ефект. Вона провокує недовіру студентів як до викладача, так і до самих себе. Інший варіант - похвалити одного студента, щоб таким чином показати приклад іншим, - також не дає результату. Оскільки така похвала рідко є щирою, вона принижує досягнення «зразкового» студента, але і не дає поштовху тим, на кого спрямована. Наприклад, в групі, де один студент пише роботи акуратно, а інші - ні, безглуздо приводити його роботи в приклад. Фрази типу Прекрасна робота, Філіп, і написана дуже акуратно, не те, щзо у деяких, які в різних варіантах можна почути і сьогодні, неефективні і не вирішують проблеми. Коректніше обумовити додатковий бал за гарне оформлення, або штрафні санкції за його відсутність.

Висновки. Теоретичні дослідження про роботу мозку, а також опитування очікувань покоління $\mathrm{Z}$ показують зростаючу неефективність традиційних авторитарних стилів комунікації. В той же час, некоректне застосування сучасних інструментів, на кшталт, позитивного підкріплення, також призводить до негативних результатів. Це особливо актуально і важливо в освітньому середовищі, бо навіть у студентському віці формування мозку людини ще не завершено.

Дане дослідження призначено, перш за все, викладачам факультетів іноземної філології педагогічних вишів, випускники яких потім зможуть використовувати запропоновані інструменти у своїй професійній діяльності. Застосовуючи їх, викладач іноземної мови може стати «гуманним менеджером», здатним вислухати студента, встановити 3 ним доброзичливі відносини, засновані на довірі, і при цьому утримувати високу якість навчання іноземної мови. Непрямим результатом їх застосування стають підвищення 
залученості, якості освіти за рахунок ефективного зворотного зв'язку i зниження стресового навантаження на студентів.

Розглянуті в статті інструменти конструктивної комунікації ефективні, прості й щирі в застосуванні. Разом з тим, вони вимагають формування у викладача звички їх використання. У разі відсутності такої звички можуть бути ефективними тренінгові програми, націлені на розвиток i закріплення використання в повсякденній освітній практиці нових для викладача комунікативних інструментів.

Перспективи подальших розвідок. В подальшому перспективними $\epsilon$ грунтовні дослідження в трьох напрямах: щодо зв'язку стилів спілкування 3 боку викладачів та рівнем стресу, задоволення від навчання у студентів, а також з вибором абітурієнтів ЗВО для навчання.

\section{Jimepamypa}

1. Doran G.T. There's a S.M.A.R.T. way to write management's goals and objectives. Management Rewiew. Vol. 70, Issue 11. 1981. P. 35-36.

2. Gordon Th. Message-je: exemple de mise en pratique. URL: http://www.ateliergordon.com/message-je-exemple-de-mise-en-pratique.

3. Gueguen C. Pour une enfance heureuse: repenser l'education a la lumiere des dernieres decouvertes scientifiques. P.: Robert Laffont, 2015. 216 p.

4. La Grande InvaZion: une étude sur la génération $Z$. Une grande enquête signée BNP Paribas et The Boson Project sur la Génération $Z$ et sa vision de l'entreprise. URL: https://cdn-actus.bnpparibas.com/files/upload/2015/01/20/docs/ lagrandeinvazionbnpptbp.pdf

5. Myers W., Rosenberg M. Pratique de la communication non violente. P.: Jouvence, 2007. 95 p.

6. Positive education: positive psychology and classroom interventions / Seligman Martin E. P., Ernst Randal M., Gillham Jane, Reivich Karen and Mark Linkins. Oxford Review of Education. 2009. Vol. 35, №. 3. P. 293-311. URL: http://www.ppc.sas.upenn.edu/positiveeducationarticle2009.pdf

7. The Gen $Z$ effect. Research realized by Dell Technologies. URL: https://www.delltechnologies.com/en-us/perspectives/gen-z.htm

8. Бернетт Д. Наш дивакуватий мозок / пер. 3 англ. Ю. Маричева. Х.: Віват, 2019. 384 с.

9. Медіна Дж. Правила розвитку мозку дитини / пер. 3 англ. Т. Рабчак. К.: Наш формат, 2015. 376 с.

10. Лемов Д. Мастерство учителя. Проверенные методики выдающихся учителей / пер. с англ. О. Медведь. М.: Манн, Иванов и Фербер, 2014. 416 с.

11. Оклі, Б. Навчитися вчитися. Як запустити свій мозок на повну / пер. 3 англ. А. Замоцький. К.: Наш формат, 2019. 272 с.

12. Лемов Д., Вулвей Э., Ецци К. От знаний к навыкам. Универсальные правила эффективной тренировки любых умений / пер. с англ. Н. Медведь. М.: Манн, Иванов и Фербер, 2013. 197 с. 
13. Сігел Д., Брайсон, Т. Секрети мозку. 12 стратегій розвитку дитини / пер. $з$ англ. І. Борщ. К.: Наш Формат, 2017. 192 с.

\section{References}

1. Doran, G.T. (1981). Theres a S.M.A.R.T. way to write managements goals and objectives. Management Rewiew, 70(11), 35-36.

2. Gordon, Th. Message-je: exemple de mise en pratique. Retrivered from http://www.ateliergordon.com/message-je-exemple-de-mise-en-pratique

3. Gueguen, C. (2015). Pour une enfance heureuse: repenser leducation a la lumiere des dernieres decouvertes scientifiques. P.: Robert Laffont.

4. La Grande InvaZion : une étude sur la génération $Z$. Une grande enquête signée BNP Paribas et The Boson Project sur la Génération $Z$ et sa vision de lentreprise. Retrivered from: https://cdnactus.bnpparibas.com/files/upload/2015/01/20/docs/lagrandeinvazionbnpptbp.pdf

5. Myers, W. (2007). Rosenberg M. Pratique de la communication non violente. P.: Jouvence.

6. Seligman Martin E. P., Ernst Randal M., Gillham Jane, Reivich Karen, \& Mark Linkins (2009). Positive education: positive psychology and classroom interventions. Oxford Review of Education, 35(3), 293-311. Retrivered from: http://www.ppc.sas.upenn.edu/positiveeducationarticle2009.pdf

7. The Gen $Z$ effect. Research realized by Dell Technologies (n.d.). Retrivered from: https://www.delltechnologies.com/en-us/perspectives/gen-z.htm

8. Bernett, D. (2019) Nash dyvakuvatyi mozok. Kh.: Vivat.

9. Medina, Dzh. (2015). Pravyla rozvytku mozku dytyny. K.: Nash format.

10. Lemov, D. (2014). Masterstvo uchytelia. Provieriennyie mietodiky vydaiushchykhsia uchytelei. M.: Mann, Yvanov y Ferber.

11. Okli, B. (2019). Navchytysia vchytysia. Yak zapustyty svii mozok na povnu. K.: Nash format.

12. Lemov D., Vulvei Э., \& Etstsy K. (2013) Ot znanyi $k$ navykam. Universalnyie pravyla effektyvnoi trenirovky liubykh umenyi. M.: Mann, Yvanov y Ferber.

13. Sihel D., \& Braison, T. (2017). Sekrety mozku. 12 stratehii rozvytku dytyny. K.: Nash Format. 